\title{
PROSPECTS OF USE OF VEGETABLE RAW MATERIALS IN THE TECHNOLOGY OF SOUR-MILK DESSERT
}

\author{
Uliana Kuzmyk ${ }^{1}$ \\ ukuzmik@gmail.com \\ Andrii Marynin \\ Problem Research Laboratory ${ }^{2}$ \\ andrii_marynin@ukr.net \\ Roman Svyatnenko \\ Problem Research Laboratory ${ }^{2}$ \\ Svyatnenko@i.ua \\ Yulia Zheludenko \\ Problem Research Laboratory ${ }^{2}$ \\ ulialist589@gmail.com
}

Mykhailo Kurmach

L. V. Pisarzhevskii Institute of physical chemistry of the National Academy of Sciences of Ukraine

31 Nauky ave., Kyiv, Ukraine, 03028

mazinator3710@ukr.net

Roman Shvaiko ${ }^{1}$

war.stereoplaza@gmail.com

${ }^{1}$ Department of Milk and Dairy Product Technology ${ }^{2}$

${ }^{2}$ National University of Food Technologies

68 Volodymyrska str., Kyiv, Ukraine, 01601

\begin{abstract}
Prospects for the use of vegetable raw materials in the technology of sour-milk desserts have been substantiated. According to the results of organoleptic and physicochemical parameters, a rational ratio of recipe components in the product has been established.

The results of the organoleptic evaluation show that the introduction of sublimated fruits in an amount of less than $5 \%$ does not give a pronounced taste and smell. And the introduction of dry whey protein concentrate in an amount of more than $6 \%$ contributes to a heterogeneous consistency with the presence of lumps.

It has been investigated, that with increasing the amount of sublimated fruits in the sour-milk dessert, the active acidity slowly decreased in the range of 4.8...5.4 pH units. Due to which the process of fermentation of the mixture is slow. The moisture holding index increased with the addition of sublimated fruits by an average of $4 \%$. The presence of a dry whey protein concentrate gives the products a delicate plastic consistency due to the high dispersion of whey protein micelles and the peculiarities of gelation.

Therefore, it is recommended to add sublimated fruits to the sour-milk dessert not more than $7 \%$, dry whey protein concentrate not more than $6 \%$.

The nutritional value of the sour-milk dessert in accordance with the most important components according to the daily requirement has been studied. The consumption of sour-milk dessert will ensure the content of easily digestible biologically complete milk protein within $5-8 \mathrm{~g} / 100 \mathrm{~g}$. The combination of the sour-milk base with raw fruits will provide potassium content by 166-267 g/100 g, magnesium content by 16-24 g/100 g, calcium by 135-180 g/100 g, sodium by 53-70 g/100 g.
\end{abstract}

Keywords: dessert, apple, banana, water activity, dry whey protein concentrate, moisture holding capacity.

DOI: $10.21303 / 2504-5695.2021 .001848$

\section{Introduction}

Herbal ingredients are used to expand the range of food and enrich the nutritional value of the product. Fruit and berry raw materials are the main source of biologically active 
substances, such as vitamins, phenolic compounds, minerals, etc. Such substances have immunomodulatory, radioprotective, antioxidant properties. In addition, the plant raw material has technological properties, gives the color of the product, exhibits stabilizing properties and others $[1,2]$.

The most available raw material is apple fruit, which has a high content of low molecular weight phenolic compounds. Their content (by chlorogenic acid) averages $1720 \mathrm{mg} / 100 \mathrm{~g}$. They are natural antioxidants and immunomodulators. In addition, apples contain a significant amount of biologically active substances, such as ascorbic acid $(75 \mathrm{mg} / 100 \mathrm{~g}), \beta$-carotene $(0.11 \mathrm{mg} / 100 \mathrm{~g})$, pectin, tannins and others $[3,4]$.

It has been found, that the addition of $1 \%$ apple powder before yogurt fermentation promotes the aggregation of casein micelles. As a result, it causes the onset of gelation at higher $\mathrm{pH}$ (5.9). Also, there is an increase in the stability and cohesion of the gel during storage. As evidenced by the strengthening of the structure of intact casein gels. This effect can be explained by the gelation ability of pectins and other soluble fiber, secreted from apples into milk [5].

Another most popular fruit in the world is the banana. The energy value of $100 \mathrm{~g}$ of banana pulp is very high - from 80 to $240 \mathrm{kcal}$. Raw banana pulp contains $30 \%$ of dry matter, $27 \%$ of carbohydrates, including $15-25 \%$ of sugars, $7-20 \%$ of starch, $0.5 \%$ of fiber and pectin, $0.3-0.6 \%$ of essential oil. The pulp contains up to $1.3 \%$ of proteins, which contain the essential amino acid tryptophan. Isovaleric, isoamyl esters and isoamyl acetate give a peculiar aroma to fruits. The vitamin complex consists of vitamin $\mathrm{C}-37-53 \mathrm{mg} / 100 \mathrm{~g}, \beta$-carotene - up to $30 \mathrm{mg} / \mathrm{kg}$, vitamins B1 - 0.04-0.07 mg/100 g, B2 - 0.02 and B3 - 0, 2-0.3 mg/100 g, as well as vitamins B6, PP, E. The mineral composition of bananas is rich and varied. It is represented by $\mathrm{mg} / 100 \mathrm{~g}$ of calcium (8-33), phosphorus (21-38), iron (0.4-1.4), sodium (1-5), magnesium (42), copper (0.16), zinc (0.2), potassium (370-401) [6, 7].

Biologically active substances of vegetable raw materials, their functionality determine the urgency of creating new products.

A promising area is the development of resource-saving food technologies, namely the development of innovative products using raw materials of plant and animal origin.

\section{Research aim and tasks}

The aim of the study is to develop a sour-milk dessert. This will make it possible to improve typical products using raw materials of plant and animal origin.

This goal was solved by solving the following tasks:

- substantiate and establish a rational ratio of components in the composition of sourmilk dessert;

- calculate the nutritional value of fermented milk product.

\section{Materials and Methods}

Model samples were prepared as follows: dry whey protein concentrate and sublimated fruits were added in skimmed pasteurized milk at a temperature of $40-45^{\circ} \mathrm{C}$, The gelatin was pre-soaked in cold water for at least 30 minutes, then the solution was heated to a temperature of $55-65^{\circ} \mathrm{C}$ with stirring until completely dissolved.

The resulting milk mixture was heated to $80^{\circ} \mathrm{C}$ with stirring, a solution of gelatin was added and heated to $90{ }^{\circ} \mathrm{C}$ for $50-60 \mathrm{~s}$ for pasteurization. The mixture was then cooled to a temperature of $55-60{ }^{\circ} \mathrm{C}$, mixed thoroughly, cooled to a fermentation temperature of $38-42{ }^{\circ} \mathrm{C}$, and a direct application yeast was added. It consists of microorganisms of bifidobacteria and lactobacilli that include Streptococcus thermophilus, Lactobacillus delbrueckii ssp. Bulgaricus, Lactobacillus acidophilus, Bifidobacterium lactis, Lactobacillus casei, Lactobacillus rhamnosus, Lactobacillus paracasei, Bifidobacterium infantis.

The mixture was stirred for 15-20 min and fermented for $8 \mathrm{~h}$ until a strong clot formed. Subsequently, the samples were cooled for $8-16 \mathrm{~h}$ to a temperature of $4 \pm 2{ }^{\circ} \mathrm{C}$. 
The organoleptic evaluation of the sour-milk dessert was performed by the method of describing open tastings, using a 10-point scale.

The nutritional value of the sour-milk dessert was determined by calculating the percentage of compliance of the integrated score of each of the most important components according to the daily requirement [8].

The energy value was calculated by the formula:

$$
\mathrm{E}=4 \times P+9 \times F+4 \times C,
$$

where $P, F, C$ - mass fraction of proteins, fats and carbohydrates in the product, respectively $(\mathrm{g} / 100 \mathrm{~g}) ; 4,9,4$ - thermal energy, released during the burning of $1 \mathrm{~g}$ of proteins, fats, carbohydrates, respectively (kcal).

The determination of active acidity $(\mathrm{pH})$ was carried out according to DSTU 8550: 2015. The determination of active acidity was carried out at a product temperature of $20 \pm 2{ }^{\circ} \mathrm{C}$. In a clean, dry beaker, about $40 \mathrm{~cm}^{3}$ of the fermented milk product is taken, electrodes are immersed in it and after $10 \ldots 15 \mathrm{~s}$ the readings are taken on the scale of the device.

Moisture holding capacity (MHC) was determined by the gravimetric method of GrauHamm in the modification of A. A. Alekseev, which is based on determining the amount of moisture, released from the product by light pressing. To do this, a batch weighing $0.3 \mathrm{~g}$, weighed to the nearest $0.001 \mathrm{~g}$ was placed on a soft waterproof plate with a diameter of $40 \mathrm{~mm}$, covered with a slowly absorbing ashless filter with a diameter of $40 \mathrm{~mm}$, then covered with a glass plate with a diameter of $100 \mathrm{~mm}$ and placed on it a weight of $500 \mathrm{~g}$. After 7 minutes, the plate was removed and the plate with the batch was weighed. The MHC was determined by the formula:

$$
M H C=(100 \cdot(a-b)) / a,
$$

where $M H C$ - moisture holding capacity, $\% ; a$ - the amount of moisture in the batch, g; $b$ - the amount of moisture, released from the batch of cheese, $\mathrm{g}$.

$$
a=0.3 M_{h} / 100,
$$

where 0,3 - cheese batch, $\mathrm{g} ; M_{h}$ - moisture mass fraction, $\%$ [9].

The study of water activity (Aw) (relative humidity, \%) was performed on a water activity analyzer «HygroLab 2» (Rotronic, Switzerland) at a temperature of $20^{\circ} \mathrm{C}$ in the measuring range $0 . .1$ Aw $(0 . .100 \% \mathrm{rh})$.

HygroLab 2 (Rotronic, Switzerland) is a desktop laboratory humidity and temperature analyzer with a display and control keys, to which 1-4 water activity probes are connected simultaneously. The analyzed sample is taken in a container and placed in the measuring chamber. A water activity probe is installed on top. The measurement cycle lasts 3-5 minutes, after which the display shows the values of water activity and temperature for each probe.

The obtained measurement results and graphical presentation of experimental data were performed using standard statistical processing programs Microsoft Excel 2010. The accuracy of the obtained results was ensured by the three-fivefold repetition of experiments.

\section{Results}

The creation of functional dairy products with the introduction of secondary resources is relevant. Therefore, at the first stage of work model samples were prepared in order to determine the rational ratio of components in the composition of the sour-milk dessert.

The research results were systematized and shown in Table $\mathbf{1 .}$

Model samples with different content of recipe components are shown in Fig. 1. 
Table 1

Characteristics of organoleptic parameters of model samples with different content of component composition

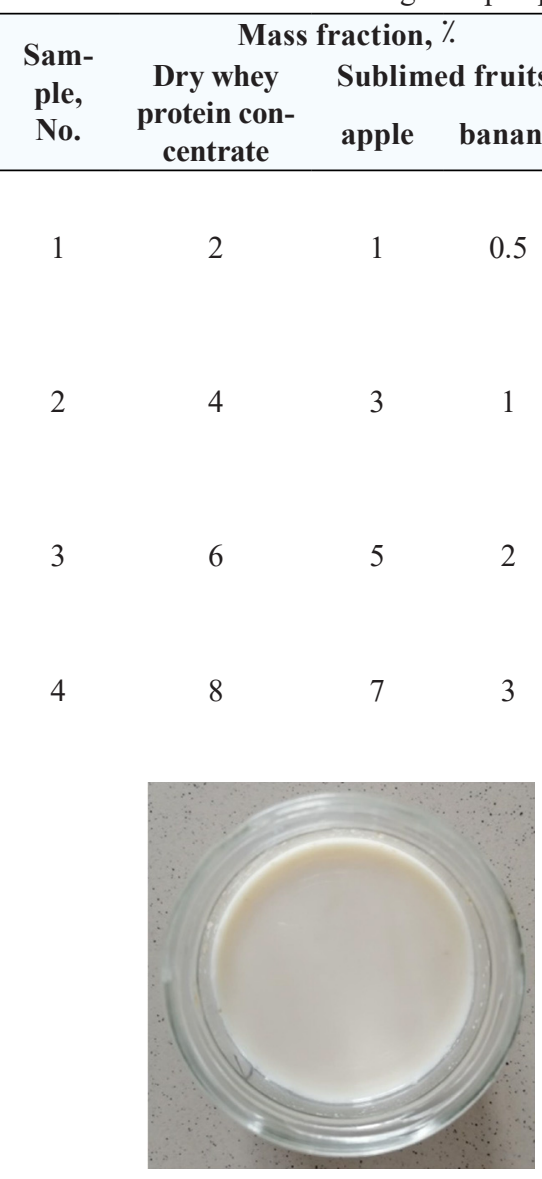

$a$

Taste and smell

Pure, milky, moderately sweet, with an inexpressible taste and aroma of sublimated fruit

Pure, milky, moderately sweet, with a pronounced taste and aroma of sublimated fruit

Pure, milky, moderately sweet, with a pronounced taste and aroma of sublimated fruit

Pure, sweet, with a pronounced taste and aroma of sublimated fruit

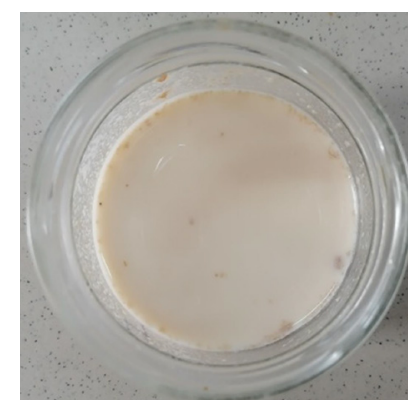

$b$
Color and consistence

The consistency is homogeneous, tender, not glossy enough.

The color is milky, uniform throughout the mass

The consistency is homogeneous, tender, the surface is glossy, jelly-like.

Milk color with a cream tint, uniform throughout the mass

The consistency is homogeneous, tender, the surface is glossy, jelly-like.

Milk color with a cream tint, uniform throughout the mass

The consistency is heterogeneous, the presence of lumps, the surface is matte, jelly-like.

The color is cream, uniform throughout the mass

Fig. 1. Model samples with different content of recipe components: $a$-sample No. $1 ; b$-samples No. 2, 3; $c$-sample No. 4

According to the results of the organoleptic evaluation of model samples, it is advisable to choose a sample No. 2 and No. 3. These results show that the introduction of sublimated fruit in the amount of $1.5 \%$ does not give a pronounced taste and smell. And the introduction of a dry concentrate of whey protein in the amount of $8 \%$ contributes to the heterogeneous consistency with the presence of lumps.

Due to the balanced ratio of basic food components: proteins, fats, carbohydrates, minerals, vitamins, fermented milk products have dietary properties. Therefore, determining the nutritional value of the sour-milk dessert is important and relevant.

The calculation of the chemical composition and nutritional value according to the content of essential nutrients [10] are shown in Table 2.

The consumption of the sour-milk dessert allows to ensure the content of easily digestible biologically complete milk protein in the range of 5-8 g/100 g. Sour-milk dessert contains such important mineral elements as calcium, phosphorus, magnesium, potassium, iron. Therefore, the combination of the sour-milk base with fruit raw materials allows to provide the content of potassium at $166-267 \mathrm{~g} / 100 \mathrm{~g}$, magnesium at $16-24 \mathrm{~g} / 100 \mathrm{~g}$, calcium at 135-180 g/100 g, sodium at $53-70 \mathrm{~g} / 100 \mathrm{~g}$.

This combination will also enrich the product with vitamins $\mathrm{A}$ - up to $0.03 \mathrm{mg} / 100 \mathrm{~g}, \mathrm{C}-\mathrm{up}$ to $2.5 \mathrm{mg} / 100 \mathrm{~g}$, group B up to $1.6 \mathrm{mg} / 100 \mathrm{~g}$. 
Table 2

Chemical composition and nutritional value of the sour-milk dessert with different content of the component composition

\begin{tabular}{|c|c|c|c|c|}
\hline \multirow{3}{*}{ Food substances } & \multicolumn{4}{|c|}{ The content of nutrients in $100 \mathrm{~g}$ of the sour-milk dessert } \\
\hline & \multicolumn{4}{|c|}{$\begin{array}{l}\text { Sample, No. } \\
\end{array}$} \\
\hline & 1 & 2 & 3 & 4 \\
\hline proteins & 5.0 & 6.0 & 7.0 & 8.8 \\
\hline fats & - & - & - & - \\
\hline carbohydrates & 4.0 & 4.0 & 10.0 & 13.0 \\
\hline moisture & 86.0 & 81.0 & 75.0 & 69.0 \\
\hline \multicolumn{5}{|c|}{ Mineral substances, mg } \\
\hline sodium & 53.0 & 56.0 & 65.0 & 70.0 \\
\hline potassium & 166.0 & 185.0 & 235.0 & 267.0 \\
\hline calcium & 135.0 & 150.0 & 165.0 & 180.0 \\
\hline magnesium & 16.0 & 18.0 & 22.0 & 24.0 \\
\hline iron & 0.6 & 0.6 & 0.7 & 0.8 \\
\hline \multicolumn{5}{|c|}{ Vitamins, mg } \\
\hline $\mathrm{C}$ (ascorbic acid) & 1.5 & 1.5 & 2.0 & 2.5 \\
\hline B'(thiamine) & 0.3 & 0.3 & 0.3 & 0.3 \\
\hline $\mathrm{B}^{r}$ (riboflavin) & 1.6 & 1.6 & 1.6 & 1.6 \\
\hline A (retinol) & 0.03 & 0.03 & 0.03 & 0.03 \\
\hline \multicolumn{5}{|c|}{ Essential amino acids, $\mathbf{m g}$} \\
\hline valine & 100.0 & 94.0 & 87.0 & 80.0 \\
\hline leucine & 192.0 & 180.5 & 168.0 & 154.0 \\
\hline isoleucine & 84.0 & 79.0 & 73.0 & 67.0 \\
\hline tryptophan & 168.0 & 158.0 & 146.0 & 134.0 \\
\hline threonine & 94.0 & 88.0 & 82.0 & 75.0 \\
\hline lysine & 165.0 & 154.7 & 144.0 & 132.0 \\
\hline methionine & 52.0 & 48.9 & 45.0 & 42.0 \\
\hline phenylalanine & 181.0 & 170.0 & 157.0 & 144.0 \\
\hline Energetic value, $\mathrm{kcal} / 100 \mathrm{~g}$ & 36.0 & 40.0 & 68.0 & 87.2 \\
\hline
\end{tabular}

The calculation of the energy value indicates that the caloric content of the sour-milk dessert is in the range of $36-87.2 \mathrm{kcal} / 100 \mathrm{~g}$.

Thus, the consumption of the sour-milk dessert will halve the caloric content of foods.

The next step was to investigate the effect of recipe components of the sour-milk dessert on its physicochemical parameters.

There is studied the active acidity of model samples by different content of components (Fig. 2), the ratio of which is shown in Table 1.

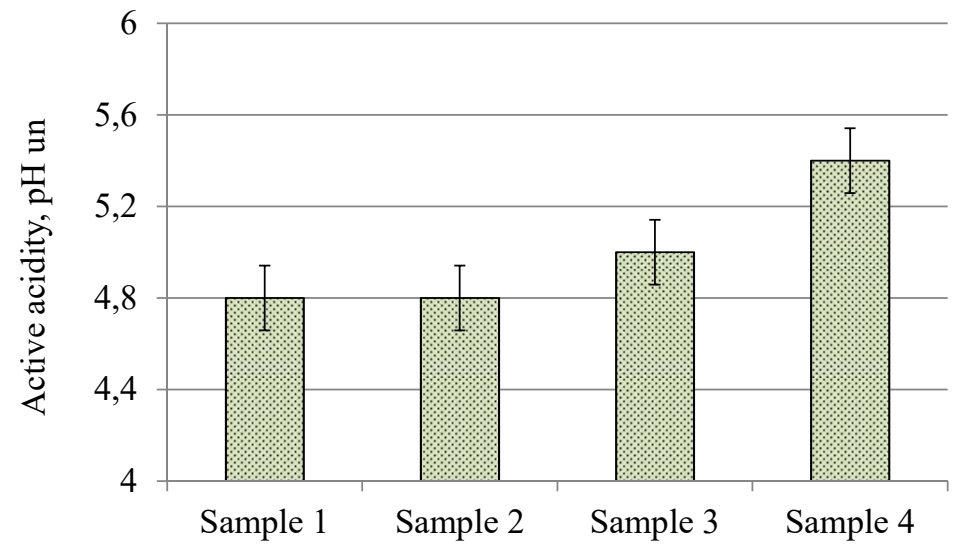

Fig. 2. Active acidity of model samples 
It has been found, that the studied samples were characterized by values of active acidity in the range of 4.8..5.4 $\mathrm{pH}$ units. As the increased amount of sublimated fruits was added to the sour-milk dessert, the active acidity index slowly decreased and thus the fermentation process of the mixture was slow. Therefore, we can recommend the amount of sublimated fruit no more than $7 \%$ of the total amount of milk mixture.

The main characteristic of fermented milk products is MHC and water activity index, so the effect of recipe components at different ratios on these parameters was determined in further studies (Fig. 3, 4).

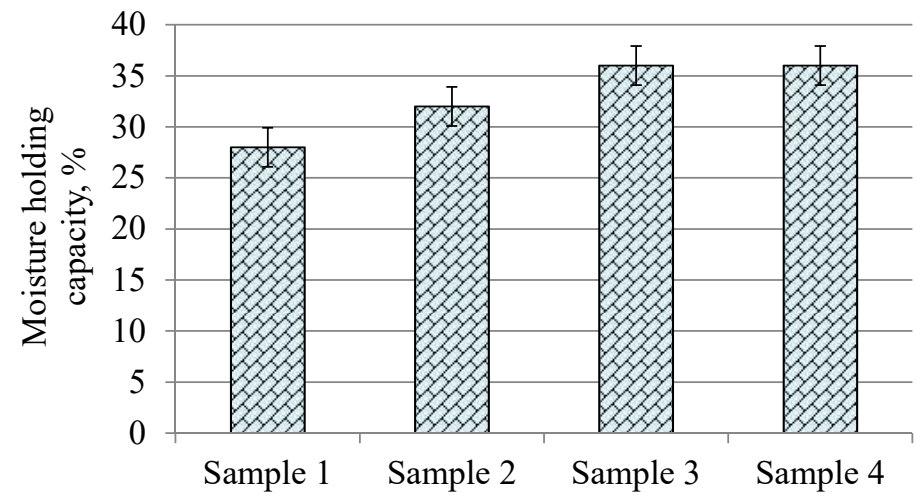

Fig. 3. Moisture holding capacity of model samples

In Fig. 3, we see that the rate of MHC increased with the addition of sublimated fruits by an average of $4 \%$. This is because the apple and banana contain soluble fiber, which allows you to retain free moisture. The presence of dry whey protein concentrate gives the products a delicate plastic consistency due to the high dispersion of whey protein micelles and gelation, and have the high biological value, so they can serve as an additional enriching component.

A similar relationship was observed for water activity.

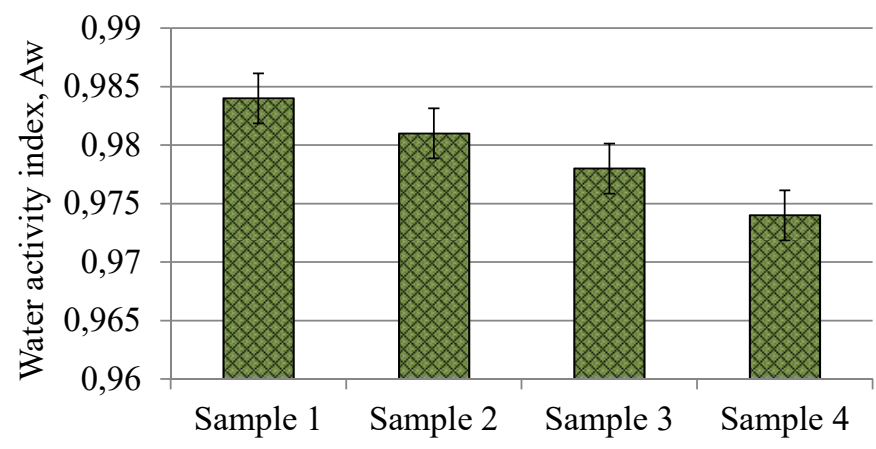

Fig. 4. Water activity index of model samples

If the increased amount of sublimated fruit was added to the sour-milk dessert, the water activity index decreased. Decreasing the activity of water increases the binding energy in the material and, as a rule, reduces the ability of microorganisms to use moisture for metabolism, reduces the rate of most chemical reactions, responsible for spoilage of fermented milk products.

\section{Conclusions}

According to the results of organoleptic and physicochemical studies, the rational ratio of components in the composition of the sour-milk dessert has been substantiated and established. It is recommended to add no more than $7 \%$ of sublimated fruits, no more than $6 \%$ of dry whey protein concentrate to the sour-milk dessert. 
The nutritional value of the sour-milk dessert in accordance with the most important components according to the daily requirement has been studied. The consumption of the sour-milk dessert will halve the caloric content of foods.

\section{References}

[1] Shtonda, O., Pasichnyi, V. (2019). Prospects of use of fruit-berry raw materials in the technology of meat natural semi-filled products. Scientific Works of National University of Food Technologies, 25 (6), 194-200. doi: https://doi.org/10.24263/ 2225-2924-2019-25-6-25

[2] Kapetanakou, A. E., Passiou, K. E., Chalkou, K., Skandamis, P. N. (2020). Assessment of Spoilage Potential Posed by Alicyclobacillus spp. in Plant-Based Dairy Beverages Mixed with Fruit Juices during Storage. Journal of Food Protection, 84 (3), 497-508. doi: https://doi.org/10.4315/jfp-20-298

[3] Pavliuk, R. Yu., Poharska, V. V., Berestova, A. A., Kriachko, T. V., Lavrynenko, V. V. (2010). Innovatsiyni tekhnolohiyi funktsionalnykh tonizuiuchykh napoiv ta dresinhiv z vykorystanniam molochnoi syrovatky ta nanostrukturovanoho plodoovochevoho piure. Naukovi pratsi [Odeskoi natsionalnoi akademiyi kharchovykh tekhnolohiy], 38 (2), 239-244. Available at: http://nbuv.gov.ua/UJRN/ Np_2010_38(2)__60

[4] Antonenko, A., Kravchenko, M. (2009). Naukove obgruntuvannia i rozroblennia fruktovykh system yak osnovy dlia solodkykh sousiv. Tovary i rynky, 2, 76-83. Available at: http://nbuv.gov.ua/UJRN/tovary_2009_2_12

[5] Wang, X., Kristo, E., LaPointe, G. (2019). The effect of apple pomace on the texture, rheology and microstructure of set type yogurt. Food Hydrocolloids, 91, 83-91. doi: https://doi.org/10.1016/j.foodhyd.2019.01.004

[6] Yingyuen, P., Sukrong, S., Phisalaphong, M. (2020). Isolation, separation and purification of rutin from Banana leaves (Musa balbisiana). Industrial Crops and Products, 149, 112307. doi: https://doi.org/10.1016/j.indcrop.2020.112307

[7] Khandoha, I. O., Kyslychenko, V. S., Burlaka, I. S., Burlaka, Y. S., Omelchenko, Z. Y. (2017). Banan - dzherelo pektynovykh rechovyn. Suchasni dosiahnennia farmatsevtychnoi tekhnolohiyi i biotekhnolohiyi, 3, 311-313.

[8] Yushchenko, N., Kuzmyk, U., Kochubei-Lytvynenko, O., Yatsenko, O. (2020). Determining the expediency of using protein-polysaccharide complexes based on dairy and vegetable proteins in the technology of butter pastes. Eastern-European Journal of Enterprise Technologies, 6 (11 (108)), 37-44. doi: https://doi.org/10.15587/1729-4061.2020.217940

[9] Yushchenko, N., Kuzmyk, U., Kochubei-Lytvynenko, O. K.-L., Yatsenko, O., Belemets, T. (2020). Prospects of using non-fried buckwheat groats in first dishes technology. EUREKA: Life Sciences, 6, 58-65. doi: https://oi.org/10.21303/ 2504-5695.2020.001542

[10] Nakaz No. 272 MOZ Ukrainy vid 18.11.1999 r. Pro zatverdzhennia Norm fiziolohichnykh potreb naselennia Ukrainy v osnovnykh kharchovykh rechovynakh ta enerhiyi. Available at: https://zakon.rada.gov.ua/laws/show/z0834-99\#Text

How to cite: Kuzmyk, U., Marynin, A., Svyatnenko, R., Zheludenko, Y., Kurmach, M., Shvaiko, R. (2021). Prospects of use of vegetable raw materials in the technology of sour-milk dessert. EUREKA: Life Sciences, 3, ??-??. doi: https://doi.org/10.21303/ 2504-5695.2021.001848 